\begin{abstract}
Despite having written hundreds of Spenserian stanzas, appearing in multiple volumes of divine poetry throughout the mid-seventeenth century, ecclesiastical lawyer Robert Aylett has been little remarked by Spenser scholars. His poems, it is widely agreed by his few commentators, are not very good. Aylett's own texts and paratexts, however, plead indulgence of their readers on the grounds that their writer is neither a poet nor a divine — but a lawyer, meddling amateurishly, with Kate Narveson's "bible readers and lay writers," in both. As well as one of the period's overlooked Spenserians, then, Aylett is also useful as a figure for disrupting Richard Helgerson's "literary system" of professional, amateur and laureate poets, to find a space instead for the committed interdisciplinarian who commits his interdisciplinarity chiefly by way of poetics. This article sets Aylett's writing in the light of current and contemporary critical approaches to interdisciplinarity, to consider the motives and mechanics of borrowing rhymes to speak devotion.
\end{abstract}




\section{A Doctor of another facultie: Robert Aylett and Early Modern Interdisciplinary Poetics}

Least I be deem'd a thiefe, I will disclose;

I turn'd to Verse what you gaue me in Prose

- Robert Aylett (1625) ${ }^{1}$

We literary scholars, it is tacitly assumed, have no definable expertise.

-Marjorie Perloff (2006) ${ }^{2}$

"I Meddle not with newes of Parlament," begins the prefatory verse to Robert Aylett's 1622 collection of divine and moral meditations, Thrifts Equipage,

Court-Fauourites, or Kingdomes gouernement;

I on Kings secrets and affaires of State,

Nor know, nor need, nor care to meditate:

Let gods, who haue the charge of all, beare sway,

The Muses must not censure, but obay. ${ }^{3}$

Shtum on the subject of parliamentary goings-on, at this particular time of writing, seems a forgivably judicious stance for a printed book of poetry. Better, in the early 1620 s, to leave it to

\footnotetext{
${ }^{1}$ I am very grateful to Hester Lees-Jeffries, Raphael Lyne, Harry McCarthy, Adam Zucker, and two anonymous readers for $E L R$, all of whose advice improved earlier versions of this essay.

Robert Aylett, The brides ornaments viz. fiue meditations, morall and diuine [...] (London, 1625), H6v .

${ }^{2}$ Marjorie Perloff, "Presidential Address 2006: It Must Change," PMLA 122, no. 3 (2007): 655.

${ }^{3}$ Robert Aylett, Thrifts Equipage viz. fiue diuine and morall meditations [...] (London, 1622), A1 ${ }^{\mathrm{v}}$.
} 
the gods, and have a quiet life. Aylett was an ecclesiastical lawyer who received his LLD from Cambridge in 1614 (the year of the Addled Parliament), beginning work as an advocate three years later. In 1628 he was appointed, one of nine, to William Laud's court of high commission, with responsibilities for combating Puritanism and upholding Laudian reforms in Essex, where he lived in the small village of Feering. Despite being named as a follower of Laud in the 1641 articles of impeachment, he retained his post as Master of Chancery between 1638 and 1642, and went on after that to become Master of the ecclesiastical Court of Faculties until 1649. Here was a man uncommonly good at keeping his nose clean. ${ }^{4}$

As a writer, however, what will survive of Robert Aylett is meddling. Neither poet nor divine, he produced in his lifetime at least nine volumes of poetry, combining meditations with scriptural paraphrases in heroic couplets and Spenserian stanzas. His collected works, running to some 480 pages, was published by Abel Roper (the uncle of the more famous political writer, who adopted and later apprenticed his nephew, and left him his copyrights in his will) in 1654, a year before his death, and a short set of devotions followed it one year later. ${ }^{5}$ Aylett's 1625 volume The Brides Ornaments follows its main dedication to then Bishop of London George Montaigne with two additional epistolary verses, each directly addressed:

To Reuerend Diuines.

Most honor'd \& belou'd! Enquire you why

A Lawyer meddles with Diuinitie?

I diue no seas profound of disputation,

But wade in shallow Fords of meditation:

I write no Systema, no Institution

\footnotetext{
${ }^{4}$ For a detailed biographical and bibliographical overview see Frederick Padelford, "Robert Aylett," The Huntington Library Bulletin 10 (1936) and "Robert Aylett: A Supplement," Huntington Library Quarterly 2 (1939).

${ }^{5}$ See G. A. Aitkin and M. E. Clayton, "Roper, Abel," Oxford Dictionary of National Biography (May 19, 2011), accessed March 2, 2020, https://doi.org/10.1093/ref:odnb/24070. Robert Aylett, Divine, and moral speculations in metrical numbers [...] (London, 1654); Devotions [...] (London, 1655).
} 
No Babels Fall, nor Sions Restitution: [...]

These mysteries I leaue to sound Diuines,

That searched haue profundest Scripture-mines,

Seditious superstitious Nouelties

I hate; my mind I onely exercise

In your pure, easie, sweet diuinest notions,

And them, at leasure, suit to my deuotions.

\section{To Iohn a Nokes}

Thou lik'st my Verses well, but not to flatter,

Dislik'st Diuinitie should be my matter.

What now? will Lawiers turne Diuines? that's braue.

No: By no meanes! They haue no soules to saue. ${ }^{6}$

Legal training in procatalepsis serves Aylett well here: voicing all objections before the opposition can get a word in, he offers a good idea of the kind of readerly hostility which might be expected by the lawyer who presumes to search out divine mysteries in print. Will lawyers turn divines? Aylett protests that this was never his intention: hating sedition and eschewing profundity, his devotional exercises are merely a gentle stretching of the legs in shallow fords, appreciating the easy sweetness of unfamiliar scenery-just leisurely strolling through. Indeed, he insists in his very first publication that:

Though indeed my Writings I intend,

For others minds and manners reformation,

Yet if hereby I may mine own amend,

I haue attained more then halfe my wished end. ${ }^{7}$

\footnotetext{
${ }^{6}$ Aylett, Brides ornaments, A2 ${ }^{\mathrm{v}}$.

${ }^{7}$ Aylett, Thrifts Equipage, 36.
} 
Might lawyers then, with easier impunity (that final pentameter, perhaps, aside) turn poets? In fact_- "but not to flatter"-Aylett's Verses have not always been so well-liked as they once were by "John a Nokes." 8 Beyond some discussion of his Song of Songs that was Salomons, in the context of other seventeenth-century Song of Songs adaptations, ${ }^{9}$ his poetry has been left largely undisturbed since two long and thorough articles written in the 1930s by Frederick Padelford, which sentenced to "prosaically pedestrian" Aylett's "interminable output of uninspired verse."10 Noam Flinker has since called this a poetic achievement "thin and mediocre at best," offering little more than "undistinguished examples of seventeenth-century imitation," "11 and Matthew Steggle — by far the kindest of Aylett's modern critics — writes charitably that, "conservative in tone," his writing is "often competent but rarely exciting.",

${ }^{8}$ Padelford, in his "Supplement" article, remarks that:

John a Nokes had apparently been frank enough to tell the author that he did not like his subject matter, for to him Aylett addressed the following quatrain [...] I have not succeeded in identifying the John No[a]kes in question, but presumably he was a friend and neighbor in Essex, for the name is common there. Thus there are Noakes Cross Farm in Braxted, Noakes Farm at Terlig, and Noakes Place at Great Baddow; and original grants date back to the thirteenth and fourteenth centuries. (473)

Padelford's characteristic scholarly tenaciousness here is admirable — but he might have done better to ask John Doe, or Erika Mustermann: John-a-Nokes, and his customary place-holding collaborator Jack-a-Stiles'fictitious name[s] for one of the parties in a legal action[;] sometimes used indefinitely for any individual person.'- are free enough with their frank advice right across the country, in countless legal tracts and pamphlets from the end of the sixteenth-century onwards. ('John-a-nokes, n.," OED Online, accessed March 2, 2020, https://www.oed.com/view/Entry/101507?redirectedFrom=john-a-nokes.)

${ }^{9}$ See Elizabeth Clarke, Politics, Religion and the Song of Songs in Seventeenth-Century England (Basingstoke: Palgrave Macmillan, 2011), 32-33, 39; Noam Flinker, The Song of Songs in English Renaissance Literature: Kisses of their Mouths (Cambridge: D. S. Brewer, 2000), 100-120.

10 Padelford, "Supplement," 478.

${ }^{11}$ Noam Flinker, “Aylett, Robert,” in The Spenser Encyclopedia, ed. A. C. Hamilton (London: Routledge, 1990), 77.

12 Matthew Steggle, “Aylett, Robert,” Oxford Dictionary of National Biography (September 23, 2004), accessed March 2, 2020, https://doi.org/10.1093/ref:odnb/932. 
Undeterred, this essay will argue that Aylett's meddling efforts to exercise his lawyer's mind (and perhaps, though essentially not essentially, the mind of his reader) in scripture-turned-stanza is revealing of unfamiliar notions of seriousness in early modern amateur poetic authorship. In writing which reaches unusually outside of its own comfortable areas of qualifications and expertise, Aylett's determination, "at leasure," to suit religious devotion to poetic structure is instructive of approaches to the suiting of divine matter to literary form in a way which I hope to show could complicate — by both its differences and its similarities_-reading poets like Aemilia Lanyer, or Mary Sidney, Henry Vaughan, George Herbert, John Donne. Aylett's prolific, opinionated inheritance of the Faerie Queene side-by-side the Bible is helpful, too, for contemplating what might be critically recuperatable, even valuable, of the nineteenth- and twentieth-century Spenser who above all things is the poet "most poetical." What did Aylett borrow or steal from "poetical" Spenser that seemed amateurishly helpful for thinking spiritual meditation by? And by what "poetical" aspects of Aylett's writing can we trace, and evaluate, these processes of reading, writing, and understanding? I hope by some of these questions to think too about our own investments, as literary scholars, in the notion of "interdisciplinarity," both its anxieties and its possibilities.

In his pivotal 1983 Self-Crowned Laureates, Richard Helgerson established terms in an early modern "literary system" composed of "amateur," "professional" and "laureate" poets. ${ }^{13}$ Helgerson's destabilising taxonomy has spurred ongoing interest in "the increasing prominence of the author as a figure in the seventeenth century,"14 proving lastingly useful as a foundation for reassessing changing modes of literary careerism, and literary celebrity. Primarily interested in Spenser, Jonson, and Milton, Self-Crowned Laureates focused foremost on the three "national" poets establishing themselves atop this newly-regulated hierarchy. "Opposition," however, as Helgerson says rightly, "is essential to constructing systems," 15 and the definition of the laureate depends for differentiation on the writer at the bottom of the pile - the "Elizabethan

\footnotetext{
${ }^{13}$ Richard Helgerson, Self-Crowned Laureates (Berkeley: University of California Press, 1983).

14 Jesse M. Lander, Inventing Polemic: Religion, Print, and Literary Culture in Early Modern England (Cambridge: Cambridge University Press, 2006), 5.

${ }^{15}$ Helgerson, Self-Crowned Laureates, 5.
} 
amateur." This figure, I think, requires some further definition of its own. The laureates of Helgerson's narrative become so by distinguishing themselves from a rabble of "unstaid wit[s] whose work is the product of idleness and lost time," by whom "poetry had been made a toy, a vanity," with "no definable bottom, no external referent, no unambiguously ascertainable meaning." 16 While the amateur "avoided print," "wrote only in youth or, more rarely, in the interstices between business," and "only for his own amusement or that of his friends," the laureate by contrast "considered writing a duty rather than a distraction," arguing with "a confidence of purpose and a sureness of moral design" for the didactic, exemplary value of his work. ${ }^{17}$ Above all, both professional and amateur writers in Helgerson's system "enjoyed" in their poetry "a freedom denied the laureate, a freedom from seriousness." 18

Caught between the oppositions of Helgerson's tripartite system, Aylett falls through the gaps. Though it is true that like these "amateurs" - in a recognisable rhetorical vein threading back "through medieval apologies to classical oratory and legend"- he "rarely began without an apology or ended without a palinode," these self-deprecations and recantations are of a different flavour to those described in Self-Crowned Laureates. ${ }^{19}$ Laurie Ellinghausen, rethinking social aspects of Helgerson's system through the industrious work of the author-labourer, has described the empowering potential of "self-conscious marginality [as] a rhetorical pose" in the writing of Isabella Whitney, Thomas Nashe, Ben Jonson, John Taylor, and George Wither. ${ }^{20}$ Like these writers' defensive self-justifications, Aylett's versions of the humility topos consist not at all in saying that his poetry or theology is bad, but only that he is not a poet or a divine.

Those "idle toys proceeding from a youngling frenzy" flung out by Helgerson's amateurs are, moreover, a far cry from what in Aylett's meditations and scriptural metaphrases are certainly

\footnotetext{
${ }^{16}$ Ibid., 67, 23, 40.

${ }^{17}$ Ibid., 29, 37, 55, 64 .

18 Ibid., 39.

${ }^{19}$ Matthew Harrison, “The Rude Poet Presents Himself: Breton, Spenser, and Bad Poetry,” Spenser Studies: A Renaissance Poetry Annual 29, no. 1 (2014): 240; Helgerson, Self-Crowned Laureates, 27.

${ }^{20}$ Laurie Ellinghausen, Labor and Writing in Early Modern England, 1567-1667 (Aldershot: Ashgate, 2008$), 7$.
} 
presented as a worthy, valuable, and serious endeavour — both for writer and reader. ${ }^{21}$ The 1621 Song of Songs introduces its new author with a typical bouquet of approving puffs by friends and admirers. All relate the written activity of the book not to idle trifling, but rather to its writer's practical devotion, exhorting that "what's there and here deliuered" in "This Worke diuine," "May daily in our liues be practised." "Of making many Bookes there is no end," one seems to concede, "And too much reading wearieth the flesh"-but, it goes on, Aylett's book is rather the exception that proves the rule, for here "more that I to reading these intend, / They more my Soule and Spirit doe refresh." 22 Peace with her foure garders, published a year later, begins by acknowledging "To the curious READER" its well-awareness that:

Prophaner Michols will be censuring

Eu'n Dauid, if hee doe but dance and sing

Before the Arke: Then how should holy Rimes

Escape the Iawes of these Censorious times ${ }^{23}$

And yet, as far as these critics are to be believed, Aylett's lines do escape the snapping of censorious jaws. This is writing which we are encouraged to think bears serious reading, and serious consideration - a use of time akin to praying, even almost synonymous with it. Fifty-six pages of holy rhymes later, far from finding their flesh wearied, the curious reader will hit upon another review, just above the FINIS, to bookend their opinion:

To the Author.

I Read thy Poems, and I them admire;

The more I reade, the more I do desire:

\footnotetext{
${ }^{21}$ Qtd. Helgerson, Self-Crowned Laureates, 5

${ }^{22}$ Robert Aylett, The Song of Song, which was Salomons metaphrased in English heroiks by way of dialogue [...] (London, 1621), A5 .

${ }^{23}$ Robert Aylett, Peace with her foure garders viz. fiue morall meditations [...] (London, 1621), A3 .
} 
They breathe such holy Passions in the mind;

Who reads them most, himselfe shall better find.

In some notable ways, then, Aylett bears more resemblance to the non-professionals explored by Kate Narveson in her Bible Readers and Lay Writers in Early Modern England-layfolk for whom "the practice of reading with pen in hand led to the practice of writing in 'Scripture phrase'." 24 Narveson's history of reading by "used books" in the conceptual rather than the material realm provides sympathetic context for Aylett's writings - and though many of her subjects write only in manuscript, it is certainly worth being clear that in a wider club of "layfolk" publishing devotion, Aylett is by no means alone .By 1640, Narveson notes,

Over forty laymen published various forms of scriptural devotion - a figure that does not include Psalm translation-while almost all women's print publications involved use of the compositional techniques that cluster around scripture reading and writing. ${ }^{25}$

Though Narveson's work would certainly encompass writers of scriptural verse (she mentions Hester Pulter, Dorothy Calthorpe, and Anne Conway), she is much more concerned with the Bible as an influence on prose style. ${ }^{26}$ For this essay it needs to matter that Aylett's compositional technique is rhymes and metres, clustering around reading and writing poetical Spenser.

Despite Aylett's paratextual claims that his devotions exercise the mind only easily, sweetly, "at leasure"- and despite Padelford's characterisation of this writing as "an escape from his onerous professional tasks" 27 — the poetry itself is fiercely interested in hard work and utilitas, in time well-spent and worthwhile. Like contemporary devotional manuals, Aylett's verse continually condemns and frets at bad readerly attention—at "idleness" and "carelessness," boredom and flitty distraction, the "slumber in our eye-lids" and the buzz in our ears which

\footnotetext{
${ }^{24}$ Kate Narveson, Bible Readers and Lay Writers in Early Modern England (Farnham: Ashgate, 2012), 3-4.

${ }^{25}$ Narveson, Bible Readers, 13, 201.

${ }^{26}$ See particularly Narveson, Bible Readers, 52-65.

${ }^{27}$ Padelford, "Robert Aylett," 47.
} 
"should not haue so tingeled" to hear stories of God's great wrath. ${ }^{28}$ Quite unlike Helgerson's "toy, pastime, play, retirement," 29 or those bad influencers Ellinghausen identifies in the Parnassus plays which present to the undergraduate by the figure of "Furor Poeticus" "poetry as a pollution of true study and a threat to virtue," ${ }^{30}$ its rulings on right occupation are strict. Thrifts Equipage contains one entire meditation (“Of Frugality, or Thrift.") on the economical use of time, and another ("Of Diligence.") on the right and wrong kinds of labour and busyness. Right readers of the Brides Ornaments must be ready and eager to spurn activities "Intemprate""drinking, Play, smoake, in excesse" - and cast aside "vaine pastime, oyle and Wine," rather to "delight / Wholly in God, and heau'nly contemplation."31 After all,

When our fraile Body doth returne to dust,

Our soule to him that gaue it must ascend,

Whereof least iot of time account they must,

Which hath been spent in discord, profit, folly, lust. ${ }^{32}$

Though it is true that for Aylett worship is often in itself delightful, and should seem so“To Know and doe God's will is delectation"- this by no means entails either "easy" or "relaxing." "All this," he maintains, "must be got with toile and sweat."33 Just as Ellinghausen's authors "represented their own writings as material work and claimed labor as a positive value for writing," 34 Aylett's good reading is often difficult, laborious and effortful—and "As Iacob with the Angell wrestled, [...] We striue and struggle for the meaning should." ${ }^{35}$ In learning and devotion, "Industry best agreeth to the mind," and constant movement and "exercitation" are

\footnotetext{
${ }^{28}$ Aylett, Brides ornaments, 19, 17.

${ }^{29}$ Helgerson, Self-Crowned Laureates, 39.

${ }^{30}$ Ellinghausen, Labor and Writing, 55.

${ }^{31}$ Aylett, Brides ornaments, 27, 41, 74.

32 Aylett, Brides ornaments, 9.

${ }^{33}$ Aylett, Brides ornaments, 6, 27.

${ }^{34}$ Ellinghausen, Labor and Writing, 1.

${ }^{35}$ Aylett, Brides ornaments, 92.
} 
vital in evading the dangers of mental stagnation. Like air, the mind "without motion putrifies," and nothing, Aylett tells us,

is more expensiue, prodigall,

Than to haue nothing here to doe at all:

Want of employment, Ease, and Idlenesse,

Haue caus'd more noble Houses here to fall,

Than Fortunes blasts, or Enuies bitternesse.

Let him not liue to spend, that nothing doth professe. ${ }^{36}$

Hence where watery metaphors in Aylett usually run teeming with productive potential"Grauitie is like the Ocean maine, / Into whose Treasure all the Flouds doe flow;" divine spirits are begged to "let your Fountaines streame as pure and cleare, / As runs the Helicon whereof you write" - the idle Lake, by contrast, where slumbering Sluggards sail, "is a filthy, muddy, standing poole," "such a muddy hole" that no good or honest mind can row at ease in it. ${ }^{37}$

Aylett's poetry, then, is more like prayer than play-more aspiring towards that worthy devotion in profane forms rendered sacred by divine matter, which we are better accustomed to discovering in John Donne, George Herbert, or Mary Sidney. Neither vacuous nor fripperous, it exercises thoughts in time wholesomely spent, and doesn't stint on character witnesses to tell us so. The final dedication to the Song of Songs volume is signed "A. Magirus," and goes as follows:

You carelesse Church-men, that your time mis-spend

In idlenesse, or worldly cogitation,

\footnotetext{
${ }^{36}$ Aylett, Thrifts equipage, 31, 11.

${ }^{37}$ Aylett, Peace with her four garders, 49, 55, 33. We might, though, recall one who did-that Phaedria of Helgerson's own self-crowned laureate Spenser, she named for "superficial pleasure and superfluous frivolity," whose wandering ship sails gaily across the Faerie Queene's great griesy Idle lake, nor caring nor fearing how swift she wends, to make port at Acrasia's "Island, waste and voyd," where Guyon is sated with slumber and false delights to forget all careful pains (II.vi.10-11).
} 
Learne of the Learned in the Lawes, to spend

Your idle time in holy Meditation.

Deuout Ciuilians of our English Nation,

Besides their true discharge of publique place,

Giue faire example, worthy imitation,

By learned Pen, to season soules with grace.

Hayward, in Prose; our Authour here in Verse,

Both Doctors of another facultie,

Doe sacred heau'nly Mysteries reherse,

As if they did professe Diuinitie

Goe on (braue Spirits) while your deuouter Lines

Shame them that falsly call themselues Diuines. ${ }^{38}$

Of course, reading scripture is partly difficult for Aylett—wading in the shallow fords of meditation - because he is, by his own admission, not a qualified theologian. But this paratext complicates the issue. Lay writing culture as Narveson sets it out "existed in uneasy relation to the official culture that was both its inspiration and its rival," sometimes with half an eye to circulation which might aid others in their devotions, in other cases entirely devoid of any such aspirations. ${ }^{39}$ It is true that a lawyer is unlikely to have much to offer even careless Church-men, in unravelling sacred heavenly mysteries - but might he be able to teach them better ways of thinking, more studious kinds of learning? Magirus sets the anti-expert lay-theoriser, the "Doctor of another facultie," against those who "professe Diuinitie" by profession-and, crucially, here, the juxtaposition flatters the amateur.

"Hayward, in Prose," in Magirus's third stanza, is a richly telling associate. Probably civil lawyer Sir John Hayward-like Aylett, sometime Master in Chancery (in 1616), and primarily

\footnotetext{
${ }^{38}$ Aylett, Song of songs, A7 .

${ }^{39}$ Narveson, Bible Readers, 5-6.
} 
famous now for his suspected treasonous support of the earl of Essex in the preface to his 1599 Life and Raigne of King Henrie IIII-Hayward-in-prose was known primarily as a writer of history books; but he was primarily popular as a writer of works of devotion. Narveson includes him in her "roll call of the better sort-judges and utter-barristers, holders of property and public office, men who also wrote on history, politics, and the law." ${ }^{40}$ Hayward's first publication of this kind, The Sanctuarie of a Troubled Soule, was written during his imprisonment in the Tower in 1600, and went through many multiple editions throughout the first part of the seventeenth century. A year after Aylett's Song of Songs, in 1622, Hayward published Davids Teares, a book on psalms whose preface has a self-deprecatory strain strangely concordant with Aylett's. "The rich compositions of Ancient times," he writes,

doe not only satisfie, but astonish mee. I see them not to the depth, but I see them so farre, that I conceive the farthest reach of our age cannot neetely approach them. Of mine own productions, never did any fully content me [...] They may happily bee somewhat sprinkled over, but throughly dyed, I conceive they are not [...] Assuredly knowing mine ignorance, and defects, I wonder much at the constant assurance of many others.

But modesty forbids us to speake good or ill of our selves. I have here undertaken a difficult taske, in writing upon these high parts of Scripture. ${ }^{41}$

Despite his modesty, public esteem of Hayward seems intriguingly constituted as approbation specifically for a writer from outside the faculty who is yet more learned than many within itand perhaps, in truth, one more "wise" in theology than he is in law. His entry in Athenae Oxonienses recounts that, "In the year 1619 he received the honour of knighthood from his

\footnotetext{
${ }^{40}$ Narveson, Bible Readers, 21. See John J. Manning, "Hayward, Sir John," Oxford Dictionary of National (January 3, 2008), accessed March 2, 2020, https://doi.org/10.1093/ref:odnb/12794.

${ }^{41}$ John Hayward, Davids Teares (London, 1622), A3v .
} 
majesty at Whitehall, being then accounted a learned and godly man, and one better read in theological authors than in those belonging to his own profession." 42

Writing - "rehearsing" - only "as if" they did profess divinity, Aylett and Hayward boast pens whose devouter lines put to shame many of those who really do profess it. As "Deuout Ciuilians" offering worthy paradigms, despite loudly proclaiming themselves amateurs, they are more akin to Helgerson's vocational and nationalistic laureates who considered writing a duty rather than a distraction, believing that only through poetry could they "properly fulfil themselves and display their gentility [...] in the active service of the commonwealth." ${ }^{43}$ Aylett brings a student's diligence and a lay-person's ingenuous hermeneutic to efforts in the exercises of divinity, and the industry of poetry. In return, I would like to suggest, divinity in one meddling hand offers him a serious occupation, and poetry in the other a different way of reading and engaging with its texts.

\section{Aylett and Literary Interdisciplinarity}

Ellinghausen's labourers, like Helgerson's laureates before them, and indeed like Narveson's layfolk, "struggle to articulate a position that has no language of its own yet." ${ }^{44}$ In his later Forms of Nationhood, Helgerson experimented with testing the borders between what he describes as "different discursive communities"- "poets, lawyers, chorographers, propagandists [...] playwrights, and churchmen"-all contemporaneously "writing England," in their own different languages, with largely similar aims. "The boundaries between such communities," he wrote, "were erected and reinforced as a function of the Elizabethan writing of England"-but "the walls between them were less solid than they sometimes seem," and in himself "crossing as well as observing them," Helgerson identified a major part of his project's methodological

\footnotetext{
${ }^{42}$ Anthony à Wood, Athenae Oxonienses: an exact history of all the writers and bishops who have had their education in the Univeristy of Oxford [...] (London, 1813), 368.

${ }^{43}$ Helgerson, Self-Crowned Laureates, 28-29.

${ }^{44}$ Ellinghausen, Labor and Writing, 6.
} 
undertaking. ${ }^{45}$ Rather than the whimsical pastime of a trifling amateur, or the imprudent interferences of an inexpert hobbyist, the rest of this essay will seek to articulate Aylett's readerwriter interactions by the language of a different discursive label: that of the dedicated and industrious interdisciplinarian.

Of John Donne, Jeremy Maule once said that the Dr. Dean Poet "was amongst other things (it is not a difficult idea) a lawyer." 46 In a discipline, however, where we tend even within literary criticism, as Matthew Harrison has put it, "to resolve early modern poetics into distinct practices, styles, and fashions [...] to give form to literary history," it is quite a difficult idea-with quite difficult implications. ${ }^{47}$ "Interdisciplinarity," an activity which only grew out of its hybridising inter-disciplinary hyphen in the mid-1950s, is plainly anachronistic to early modern writing. As it stalks the corridors of twenty-first century scholarship, it is a figure which casts a charged shadow: disparaged and demanded, glorified, ridiculed, thought serious, specious, important, disempowering, enabling, disingenuous, the object of both high suspicion and high idealism. The weighty 2010 Oxford Handbook of Interdisciplinarity, a volume its editors proclaim to have been "ten years in the making," describes in its introduction how "Interdisciplinarity" often functions apophatically: it announces an absence, expressing our dissatisfaction with current modes of knowledge production," and contains — or disguises? evades? confronts?_-"a collective unconscious of worries about the changing place of knowledge in society." 48 Remarking the power of "communication" between faculties to highlight and discombobulate what becomes the overhabituated "selective attention" of unexamined disciplinary focus, one contributor to this

\footnotetext{
${ }^{45}$ Richard Helgerson, Forms of Nationhood: The Elizabethan Writing of England (Chicago: University of Chicago Press, 1992), 5-6.

46 Jeremy Maule, "John Donne and the Words of the Law," in John Donne's Professional Lives, ed. David Colclough (Cambridge: D. S. Brewer, 2003), 22. See also Kate Narveson, "Donne the Layman Essaying Divinity," John Donne Journal 28 (2009): 1-30.

${ }^{47}$ Harrison, "The Rude Poet," 246.

${ }^{48}$ Robert Frodeman, The Oxford Handbook of Interdisciplinarity, ed. Robert Frodeman, Julie Thompson Klein and Carl Mitcham (Oxford: Oxford University Press, 2010), vii, xxxii.
} 
collection argues for interdisciplinarity as the vital "irritation" of critical work, which "provides scholars with fresh ideas and triggers them to redirect their research."

Doorkeepers and guardsmen - jealous, watchful classifiers of types of knowledge reserved for select knowers - abound in Aylett's verse, patrolling boundaries and chastising misplaced or overeager curiosity. The meditation "Of Prouidence" in Thrifts Equipage is persistently concerned with the perils of overstepping one's intellectual station, the imprudency of upstarts who "Presume [...] to be wise aboue [their] skill." ${ }^{50}$ The world, we read, may be compared to a Stage, and we mortals to Spectators; such groundlings must be careful not to mount above their reach, for:

The curious that about the Stage do stray, And pry into the secret tyring roome, Are by Stage-keepers often driu'n away:

All must not into Natures secrets come,

Although she many Mysteries reueale to some. ${ }^{51}$

As we have seen, Aylett remains interested nonetheless in disciplinarians (those careless Churchmen) who might need irritating. In rearranging scripture into Spenserian stanzas, he is not so much overreaching, as trying out words in a different space, to see if it makes them speak or echo differently. Never aiming to overgo — neither the poets at poetry, nor the divines at divinity - he bustles, rather, in-between, applying the framework of one thing to another, and hoping in the process to say something useful to both. This is interdisciplinary work.

Literary critics have not always been entirely at ease about a brave new world in which, scare quotes indispensable, "The hallmark of research [...] is "interdisciplinary'."52 In a preface to the

\footnotetext{
${ }^{49}$ Wolfgang Krohn, "Interdisciplinary Cases and Disciplinary Knowledge," in Oxford Handbook of Interdisciplinarity, 31.

50 Aylett, Thrifts equipage, 21.

51 Aylett, Thrifts equipage, 21.

52 “Journal Info,” Interdisciplinary Literary Studies, accessed March 2, 2020, http://muse.jhu.edu/journal/555.
} 
updated second edition (2010) of his 2002 cultural history Interdisciplinarity - a book which definitively makes "English," and "Literature," its frames-Joe Moran notes that while "Interdisciplinarity" is now "even more of a buzzword" than it was, "there has also been something of a reaction in literary studies, much of it healthy, against the unreflexive use of the term." 53 Raphael Lyne, in a 2015 article entitled "Interdisciplinarity and Anxiety," describes the potential for exacerbating disparities of exchange, when the literary side of interdisciplinary interactions is often undergirded by "an anxious sense of inadequacy, from which people reach out to find other sources of substance and validation." 54 In her 2006 presidency of the MLA, Marjorie Perloff led a charge against what we might call the "mere-ing" of English, in purported collaborations where "the literary, if it matters at all, is always secondary[,] has at best an instrumental value." "We literary critics, it is tacitly assumed," she needled in her Presidential Address, "have no definable expertise." 55

Aylett's meditations and metaphrases, claiming to be intended for practical use in domestic devotion, offer an instance of interdisciplinary encounter where this is categorically not the case. After all, "To study form," as Allison K. Deutermann and András Kiséry remark, "is to do what literary scholars are 'supposed' to do, the kind of work that distinguishes them from the historians and anthropologists down the hall". ${ }^{56}$ Hence, when Steggle calls the Brides Ornaments "in effect, a doctrinal sermon in Spenserian stanzas," this verdict seems shrewd, but potentially bathetic - perhaps not quite sufficiently expressing the magnitude of this effort of reformation, "in effect." ${ }^{57}$ In the case of Donne, as David Colclough notes, ranging through specialised vocabularies of law, medicine and theology "has usually been seen as the sign of a truly voracious Renaissance literary mind, appropriating useful terms, magpie-like, to its own poetic

\footnotetext{
53 Joe Moran, Interdisciplinarity (London: Routledge, 2010), viii.

${ }^{54}$ Raphael Lyne, “Interdisciplinarity and Anxiety,” Palgrave Communications 1 (2015): 2.

55 Perloff, "It Must Change," 655.

${ }^{56}$ Allison K. Deutermann and András Kiséry, Formal Matters: Reading the Material fo English Renaissance Literature (Manchester: Manchester University Press, 2013), 2.

${ }^{57}$ Steggle, “Aylett, Robert,” n. p.
} 
purposes."58 While Aylett's nestwork —“"mediocre," "uninspired"-may prove ultimately less dextrous, his roving eye is as keen, and as active: irrespective of the artistic success of the enterprise, his non-expert writing carries parts of homily, scripture, and prayer out of the hands of divines, in order to transform them into what, more than anything else, is poetry and storytelling. Borrowing poetics to speak devotion, the primary plunder of his interdisciplinary reaching is literary - narrative, voice, rhyme, metre, stanza. This is an "irritating" of subject matter where it is certainly literature and poetics which do the chief work of informing and reforming.

\section{Aylett on Poets}

In asking what Aylett thinks to get out of stanzas by putting things into them, it helps to examine the stated views on poetry which might motivate this pursuit. Since the forging of any new writing character - professional, amateur, labourer, interdisciplinarian - is most importantly a work of self-fashioning by relation ("Opposition is essential to constructing systems"), ${ }^{59}$ this properly begins with a consideration of Aylett's stated opinions of other poets - particularly the kinds of poets who qualify as Helgerson's laureates, and particularly, in this case, Spenser. Where, beyond the unmistakable shape of the stanza, can we glimpse the shadow of the Faerie Queene in the Song of Songs, the Brides Ornaments, and Thrifts Equipage? Although Aylett never explicitly, as far as I can find, addresses the topic of his borrowed form, for those wont to go searching for Spenser, there are hints from place to place, if any tract of him or tydings they mote trace. Beneath the epistolary verse to the Song of Songs - a dedication to another Bishop of London, the late John King — runs an undertow which is decisively Spenserian:

As little Brookes which from the Ocean wide

Receiue their Source, thence watering hollow vaines

Of fruitfull Earth, backe to the Sea doe slide, Yeelding some Drops of Tribute for their gaines:

\footnotetext{
${ }^{58}$ David Colclough, "Introduction: Donne's Professional Lives," in John Donne's Professional Lives, 4.

${ }^{59}$ Helgerson, Self-Crowned Laureates, 5.
} 
Euen so a thankfull heart my Muse constraines,

This Tribute to your Bountie to repay,

And consecrate my labour and my paines

Vnto your Seruice, which I humbly pray,

Like Mite, to Treasure; Drop, to Ocean, answer may. ${ }^{60}$

Watery language of grateful obligation and humility is Faerie Queene talk. It is a signature particularly of Book VI's tributary choreography:

Then pardon me, most dreaded Soueraine,

That from your selfe doe it returne again:

So from the Ocean all riuers spring,

And tribute backe repay as to their King.

Right so from you all goodly vertues well

Into the rest which round about you ring, ${ }^{61}$

(Hard not to wonder if Aylett, answering like Mite to Treasure, heard "King" ringing in the veins of the source, too.) Padelford argues that Aylett, "ambitious to achieve hard-won success in his own profession," was "no less ambitious - pathetically ambitious, it would seem, in view of his interminable output of uninspired verse - to enrol himself in the immortal company of the poets. ${ }^{, 62}$ Here, I would argue, Padelford is partly mistaken; Aylett in fact is slightly to the left of ambivalent about poetic fame. His dedication to King goes on to recount how:

My Muse once rashly sought to enterprise,

To ranke thine Honour in the Court of Fame;

Not knowing Thou such Glorie didst despise,

\footnotetext{
${ }^{60}$ Aylett, Song of songs, A4 ${ }^{\mathrm{r}}$.

${ }^{61}$ Edmund Spenser, The Faerie Queene, ed. A. C. Hamilton (Harlow: Longman, 2001), VI.Proem.7. Further references will be given in the text.

${ }^{62}$ Padelford, "Supplement," 478.
} 
(In white stone seeking a new written Name,

Which he knowes onely that receiues the same: ${ }^{63}$

So too, one of the few direct mentions of Spenser, in the Proem to the first volume of the Brides Ornaments bound in the same 1621 volume, censures:

Those sublime Wits, that in high Court of Fame

Doe seeke to ranke themselues by Poesie,

Eternizing the glorie of their name

By prayse of Honour, and Cheualrie,

To some great Princes Court their youth apply,

Knights honourable actions to behold;

Chaste Ladies loues, and Nobles courtesie.

Of such haue Homer, Virgil, Spencer told,

And haue thereby their names in Fames faire Court enrold. ${ }^{64}$

As "the poet's poet," as Helgerson's first laureate, Spenser is credibly representative as a figure for early modern opinions on poetry, poets, and poetic vocation in general. "Spenserians," as defined in the 1970s by Joan Grundy and William B. Hunter, are writers with what Patrick Cheney has called "metadiscursive projects," 65 in whose work "Poetry, especially their own poetry, is [...] the chief topic discussed."66 Attitudes to fame and aspiration help situate Aylett in a literary system, and begin to build a context for what he does and does not hope to achieve as a

\footnotetext{
${ }^{63}$ Aylett, Song of songs, $\mathrm{A} 4{ }^{\mathrm{v}}$.

${ }^{64}$ Aylett, Song of songs, C2 ${ }^{\mathrm{r}}$.

${ }^{65}$ Patrick Cheney, Spenser's Famous Flight: A Renaissance Idea of a Literary Career (London: University of Toronto Press, 1993), 4.

${ }^{66}$ Joan Grundy, The Spenserian Poets: A Study in Elizabethan and Jacobean Poetry (London: Edward Arnold, 1969), 83; William B. Hunter, The English Spenserians: The Poetry of Giles Fletcher, George Wither, Michael Drayton, Phineas Fletcher, and Henry More (Salt Lake City: University of Utah Press, 1977); Michelle O'Callaghan, The "Shepheard's Nation": Jacobean Spenserians and Early Stuart Political Culture, 1612-25 (Oxford: Clarendon, 2000).
} 
poetic interdisciplinarian. Clearly, the race of wits to the top of courtly ranks is not one Aylett is entering - and yet he is not entering it in a way that, once again, differs importantly from the conventional humility topos, and confuses the issue: not only does he not seek to rank himself by poesy in any Court of Fame, he also denounces those who do.

Ironically, this is a declaration of non-association with Spenser which, patently, is strongly associated with reading Spenser. Fame and defaming are touchstones of the Faerie Queene-and Aylett's own ideas about ambition seem shaped by way of a complicated sideways glance at Book II's House of Mammon. The House of Mammon is a scene to read with Helgerson in mind, trying a slightly alternative spin on his positive configuration of poets and poetic ambition in early modern society. Spenser's Ambition, however glistering her glorious exhibition, is not easy to interpret in a positive light:

There, as in glistring glory she did sit,

She held a great gold chaine ylincked well,

Whose vpper end to highest heauen was knit,

And lower part did reach to lowest Hell;

And all that preace did round about her swell,

To catchen hold of that long chaine, thereby

To clime aloft, and others to excell:

That was Ambition, rash desire to sty,

And euery lincke thereof a step of dignity.

Some thought to raise themselues to high degree,

By riches and vnrighteous reward,

Some by close shouldring, some by flatteree;

Others through friends, others for base regard;

And all by wrong wayes for themselues prepard.

Those that were vp themselues, kept others low, Those that were low themselues, held others hard, 
Ne suffred them to rise or greater grow,

But euery one did striue his fellow downe to throw. (II.vii.46-7)

The House of Mammon is also interested in dangers of borrowing, and the risk of polluting sources. As watery as ever, "At the well head the purest streames arise," yet at the mouths which drink from it, "mucky filth his braunching armes annoyes / And with vncomely weedes the gentle waue accloyes." (II.vii.15). Hence the provenance of things, in this canto, is often worth attending to-Guyon's policy not to "receaue / Thing offred, till I know it well be gott" is shrewd (II.vii.19) — and the Cave fosters prevalent anxieties about the unease of being in someone else's territory. Interdisciplinarians take note: being caught in the wrong kind of space, or seen in its wrong quality of light, can stifle natural talent, and (or so Mammon would have us believe) warp natural beauty. His daughter Philotime, he says, ought rightly to be acclaimed the fairest woman in the world, but that "this darksome neather world her light / Doth dim with horror and deformity." (II.vii.49)

Through Mammon we also glean an idea of a space's own proprietorial fear of intruders. Like all of the Faerie Queene's more demarcated architectural spans (as against those sprawling expanses which have no outline at all), this canto is full of shibboleths and boundary-markersdoors and doorways, paranoid guardsmen and jealous defences. Mammon sits "in secret shade" (3), and piles his gold in "secret place" (II.vii.20). At the "litle dore" beside the wide gate of Hell sits "selfe-consuming Care,"

Day and night keeping wary watch and ward,

For feare least Force or Fraud should vnaware

Breake in, and spoile the treasure there in gard (II.vii.25)

Likewise outside the room of Richesse prowls a covetous sprite who

warily awaited day and night,

From other couetous feends it to defend,

Who it to rob and ransacke did intend. (32) 
Accompanied by Mammon, Guyon is suffered entry - on condition of a fiendish chaperone, "The which with monstrous stalke behind him stept, / And euer as he went, dew watch vpon him kept." (26) Great iron doors swing inexplicably open before him $(31,35)$; great iron chests and coffers, "All bard with double bends" (30), remain staunchly shut. In such poetic spaces where Aylett leases intertextual residence, how fine is the line between guest and impostor-or visitor and hostage?

Famously, Spenser's House of Mammon is itself indebted by poetic pedigree to another text much interested in the problematics of ambition and celebrity-Chaucer's "House of Fame." Aylett's despising of any rank of "Honour in the Court of Fame," better to seek that new written name "In white stone" which only God can grave, recalls by contrast those names which melted off the walls of Chaucer's proud edifice on its feeble fundament:

Tho sawgh I al the half ygrave

With famous folks names fele, That had iben in mochel wele, And her fames wide yblowe.

But wel unnethes koude I know

Any lettres for to rede

Hir names by; for, out of drede,

They were almost ofthowed so

That of the lettres oon or two

Was molte away of every name,

So unfamous was woxe hir fame. ${ }^{67}$

In this House, where "ful wonder hy on a piler / Of yren" stands "the gret Omer," on one "of tynned yren cler, / The Latyn poete Virgile," "And next hym on a piler," "Venus clerk Ovide,"

\footnotetext{
${ }^{67}$ Geoffrey Chaucer, House of Fame, in The Riverside Chaucer, gen. ed. Larry D. Benson (3 ${ }^{\text {rd }}$ ed.) (Oxford: Oxford University Press, 2008), 1136-1146. Further references will be given in the text.
} 
(1465-6, 1482-3, 1486-7) we are encouraged to hear with suspicion the claims of the famous that,

We ben everychon

Folk that han ful trewely

Deserved fame rightfully (1660-2)

With Fame, we should be, rather, always on the lookout for those who,

lyke the sweynte cat

That wolde have fish; but wostow what?

He wolde nothing wete his clowes. (1783-5)

It is just such sweynte cats- "they that wolde honour / Have, and do noskynnes labour," (17934) and those that "Han certeyn doon hyt for bounte, / And for no maner other thing," (1698-9)_that Aylett censures in his meditative condemnations of wealth and riches, and of idleness and its undeserving gains. Behind the shouldering and hurling of Spenser's unrighteous golden chain of Ambition lies Chaucer's awful heap, on which,

Thos behynde begunne up lepe,

And clamben up on other faste,

And up the nose and yën kaste,

And trodden fast on others heles,

And stampen, as men doon aftir eles. (2149-2154)

Thus, through lumbering trespass in the Houses of Fame and Mammon, Aylett implicates himself in a convolutedly ironic and disingenuous form of what Glenn Steinberg describes (in Spenser) as "prestige by association," 68 which works knottily, via imitative tropes of "literary

\footnotetext{
${ }^{68}$ Glenn A. Steinberg, “Spenser's 'Shepheardes Calender' and the Elizabethan Reception of Chaucer," English Literary Renaissance 35, no. 1 (2005): 32.
} 
self-abasement" and "inability topoi" 69 to propose its own abilities, and self-ahoist by others" bootstraps. This self-installment in Matthew Harrison's "not-so-modest lineage of self-effacing versifiers" becomes then, in Aylett's writing, a kind of allusion to allusiveness itself. ${ }^{70}$ Writing in the little boxes and the large metaphors of that "new national poet, heir to a long line of poets extending back to his native medieval heir, Chaucer, to his Continental classical heir, Virgil, and eventually to the legendary founder of poetry himself, Orpheus,"71 Aylett triangulates a conversation about poets and fame which seems to tread fast on others' heels only the louder to stamp itself down. He wishes to speak with the poets at their table, to be included in their conversations and include theirs in his, but he does not wish to be one of them.

\section{Borrowing Forms}

"Forms," writes Helgerson, "are as much agents as they are structures. They make things happen."72 Good interdisciplinarians should always consider both the strategy and the rationale for importing across normal faculty frontiers - and Aylett, fixated on purposiveness, strongly condemns novelty for the sake of novelty. How then, in the context of his curious amateurism, and his decision to read scripture through rhymes and stanzas, are we to understand Aylett's opinion of poetic form (as distinct from poets)? Thrifts Equipage begins, as usual, with a verse "To the Author:"

Vertue thine Obiect, thou her Subiect art;

Thou deck'st her in thy verse, she decks thine heart:

Each th'other doth deseruedly set foorth;

From thee her praises flow, from her thy woorth. ${ }^{73}$

\footnotetext{
${ }^{69}$ Anthony M. Esolen, “The Disingenuous Poet Laureate: Spenser's Adoption of Chaucer,” Studies in Philology 87, no. 3 (1990): 286.

${ }^{70}$ Harrison, "The Rude Poet," 240.

${ }^{71}$ Cheney, Spenser's Famous Flight, 3.

${ }^{72}$ Helgerson, Forms of Nationhood, 7.

${ }^{73}$ Aylett, Thrifts equipage, A1 ${ }^{\mathrm{v}}$.
} 
Riddled by interleaving possessive pronouns, this quatrain sets up a useful model of interdisciplinary poetics as a reciprocal construction of value and beholdenness, in the work of decking and setting forth. Which party, in such interactions, represents the object and which the subject? In devotional poetics and scriptural paraphrase, who decks whom with virtue? Which sets which forth? Which is the more deserving? Do constraints of form really make praise flow more freely?

In Aylett's writing, it is primarily incarceration in forms - the fleshly "Prison house" or "brittle shrine" " — which defines us as earthly subjects, not yet liberated by Death who comes "Like Iailour" to split from around our soul its adamantine bands. ${ }^{75}$ So too, earth-bound language properly delimits our intellectual inadequacy: since our meagre comprehension cannot ever know God's purposes in their true magnitude, "The written Word," for now, "must be our square and line, / Gods secret purpose, and reuealed Will."76 Prison houses and "little Mansions," "homely Bowres" and "glistering Towers,"77 squares and lines of verse, bring to ming Spenserian fit and contayning. Catherine Addison and Jeff Dolven have written with brilliant lucidity on Spenser's use of the stanza where "form is not a container at all but a 'perceptual condition' of the total effect or meaning," with the power to "filter and render all experience, imposing on it a particular shape, deriving from it a particular kind of lesson,"78 and this well fits a concept of poetic form as a mode of interdisciplinary reconsidering, where the stanza might offer a new way of thinking, a new kind of perceptual condition or pedagogic filter for divine meditation.

Aylett is often concerned explicitly with the forms taken by words, and by the different sizes of different kinds of linguistic utterance and proclamation, anxious about or fascinated by matter

\footnotetext{
${ }^{74}$ Aylett, Peace with her four garders, 48, 56.

75 Aylett, Thrifts equipage, 49.

76 Aylett, Thrifts equipage, 20.

77 Aylett, Peace with her four garders, A4 ${ }^{\mathrm{r}}$; Thrifts Equipage, 7.

${ }^{78}$ Catherin Addison, "Little Boxes: The Effect of Stanza on Poetic Narrative," Style 37, no. 2 (2003): 140; Jeff

Dolven, “The Method of Spenser's Stanza,” Spenser Studies 19, no. 1 (2004): 22.
} 
too large squeezed up too small — or too little in space too large, stretched out too thin or beaten too flimsy to merit holding the requisite attention of a reader or listener. This bespeaks, in some senses, an affiliation with those "Spenserians" most straightforwardly defined as poets "most at home in the long work," producing texts "massive in size and scope," where "size alone [...] seems to make a fundamental difference in artistic perception."79 "It is the spaciousness, the roominess that attracts," says Grundy, "The Spenserians like a poem that gives them a place, a space to move about in." ${ }^{80}$ But fearing audiences like Cuddie in the Shepheardes Calender, who is bored in the "February" Eclogue literally into the ground (his galage grown fast to his heel) by wasting a day in lengthy listening to "long tale, and little worth," ${ }^{1}$ Aylett is quick to recognise when "To tell what wonder haue been [...] wrought, / Were too long for this short meditation." ${ }^{\text {" } 2}$ He often marvels at the scriptural spaces of few great words with vast semantic coverage, or single phrases stacked with multiple concurrent planes of meaning, in the Psalter where David strikes the lofty string "in one Psalme a thousand times," or the Bible where "fiue examples may liue in one"-where indeed, "such rare profound deepe Learning shine, / A Volume is not able to expound a Line." 83 Interest in how much space things ought to take to speak, and how much space they do ("to study form is what literary scholars are 'supposed' to do") is to bring a distinctively literary attention to bear on the question of scriptural reading engagement, and how to hold it.

If many of Aylett's forms are God-fashioned unimpeachable, there are also those-also recognisably Spenserian — with the misleading potential to deceive. Satan, he writes in Susanna, "when he would vs worke despite,"

\footnotetext{
${ }^{79}$ Hunter, English Spenserians, 2, 4; Helgerson, Forms of Nationhood, 1.

${ }^{80}$ Grundy, Spenserian Poets, 59.

${ }^{81}$ Edmund Spenser, The Shepheardes Calender, in The Yale Edition of the Shorter Poems of Edmund Spenser, ed. William A. Oram, Einar Bjorvand, Ronald Bond, Thomas H, Cain, Alexander Dunlop and Richard Schell (London: Yale University Press, 1989), 48.

82 Aylett, Brides ornaments, 63.

${ }^{83}$ Aylett, Brides ornaments, 92, 38, 88.
} 
Transformes him to an Angell of the Light,

Lest if we should behold his proper Shape,

Forearmd, forewarnd, we might his malice scape. ${ }^{84}$

And in Urania:

But Satan since another patterne set,

Which he would haue all his to imitate;

And like a Fowler draweth to his Net

Poore Birds with merry notes and pleasing Bait. ${ }^{85}$

To "transforme"- -here, temporarily changing containers in order to look, deceitfully, like something else - is a ready threat to good reading and understanding. More fundamentally, it also creates form ("proper Shape"), and set (or imitated) pattern, in Aylett's interdisciplinary poetic reading, as an aspect of text which might be independently legible to our judgment. The cognitive activity of perceiving textual shapes, this implies, can forewarn and forearm us of meaning just as importantly as that of processing the substance which those shapes contain. Just as Noam Flinker writes that William Baldwin's "formal inscription of theme in stanza form" in his 1549 The canticles or balades of Salomon, phraselyke declared in Englysh metres "sets up a mode that later poets like George Herbert would pick up and develop," ${ }^{\prime 66}$ Aylett suggests the legibility of the disciplinary frameworks written into poetic forms, as a means of suggesting a specific way to read them.

Hence, working with form (and, undoubtedly, working with the Faerie Queene, its homely bowers, containers and loosenesses, captives in castles and wenders amiss in sprawling landscapes) also inclines Aylett's imagination of scriptural landscapes to texture and topography, to a handling of language alive to its three-dimensionality, preoccupied with trying the lightness,

\footnotetext{
${ }^{84}$ Robert Aylett, Susanna: or, the arraignment of the two vnjust elders (London, 1622), 7.

${ }^{85}$ Aylett, Brides ornaments, 114.

${ }^{86}$ Flinker, Kisses of their Mouths, 47.
} 
shallowness, soundness, height, reach, narrowness of texts and the action of reading them, with results which seem pertinent both to interdisciplinarity and to its particular functioning through poetics. We might return here to that initial qualification which preceded the second instalment of the Brides Ornaments:

I diue no seas profound of disputation, But wade in shallow Fords of meditation

Certainly, having stated the limits of his reading, Aylett is as good as his word: some things, he tells us, are "too high to reache, too deepe to sound," "by my shallow Muse their depth cannot be reade." 87 “Oh depth of Knowledge!” he exclaims, "I am drown'd, here Elephants may swim, / My Lambe-like Muse in shallow Fords must wade." ${ }^{88}$ In the Oxford Handbook of Interdisciplinarity, Robert Frodeman writes of modern scholarship that "bias for the deep rather

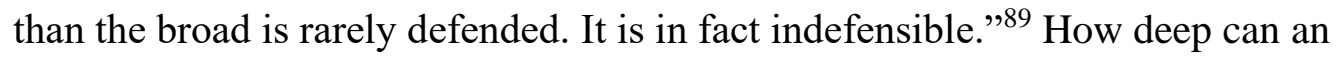
interdisciplinarian hope to go - and will poetics as a function of interdisciplinarity ever help them get there? The bias for the deep rather than the shallow-let alone the superficial - can go unsaid here, too obvious (fittingly) to bear thinking about. But might poetry as a discipline of thought ever offer a kind of thinking which is usefully surface-level? What kind of reading might valuably be achieved by—merely? —skating, skimming, and sliding?

\section{Borrowing Sensibility}

Narveson describes how "Scripture provided an idiom, indirectly as well as directly," for lay writing, citing a "sense of how godly language sounds" which developed from a young age

\footnotetext{
${ }^{87}$ Aylett, Brides ornaments, 33.

${ }^{88}$ Aylett, Brides ornaments, 6. An intriguing slight skew on the patristic axiom-identified by Arnold Hunt as "one of the most familiar of the early modern period"_- "as there are deepe places where the Elephant must swim, so there are shalow where the lamb may wade." (Arnold Hunt, The Art of Hearing: English Preachers and their Audiences, 1590-1640 (Cambridge: Cambridge University Press, 2011), 40.

${ }^{89}$ Frodeman, Oxford Handbook of Interdisciplinarity, xxxiv.
} 
through both public worship and household prayers. ${ }^{90}$ In the preface to his 1679 Paraphrase Upon the Canticles, Samuel Woodford justifies his metaphrasing project by explaining that "In Verse, the Mind is quite otherwise dispos'd, and requires naturally another kind of Movement [...] more exalted, and as it were with a different kind of light Number also and Harmony." 91 What else about "Spenserian poeticism" appeals to Aylett, beyond the stanza? Despite “dominat[ing] English poetry until well into the reign of Charles," Hunter and Grundy's "Spenserianism" tends to reside in stylistic attributes not likely wholly satisfactory to the modern critic. ${ }^{92}$ Theirs is a "highly artificial style," sensed airily in the "technique and general flavour of the descriptions." 93 Above all, and over and over again, it is a mode designated "poetic" — and often left at that. "Of all poets, Spenser is the most poetical," said William Hazlitt once: it stuck. ${ }^{94}$ Datedly misty though these critical intuitions might seem, they are worth interrogating. The "“sounds-like' argument," as Jeanne Shami has called it in Donne, "can alert us to unexpected and fruitful connections and can suggest important qualifications of received notions." "The writers I am concerned with," says Grundy, "both admired and imitated Spenser and shared his values." 96 When "Spenserianism serves as a shorthand" for what Rachel Hile, investigating Spenserian satire, has called "'Spenser' as a bundle of ideas," 97 the groups we feel moved to put people in, and into which they make efforts to put themselves, how we draw the

\footnotetext{
${ }^{90}$ Narveson, Bible Readers, 52-53.

${ }^{91}$ Samuel Woodford, A Paraphrase upon the Canticles, and some select hymns of the New and Old Testament with other occasional compositions in English verse (London, 1679), $\mathrm{C1}^{\mathrm{v}}$.

${ }^{92}$ Hunter, English Spenserians, 2.

${ }^{93}$ Israel Baroway, "The Imagery of Spenser and the 'Song of Songs'," The Journal of English and Germanic Philology 33, no. 1 (1934): 40.

${ }^{94}$ William Hazlitt, "On Chaucer and Spenser," in Lectures on the English Poets: Delivered at the Surrey Institution (London: Taylor and Hessay, 1818), 68.

${ }^{95}$ Jeanne Shami, "Labels, Controversy, and the Language of Inclusion in Donne's Sermons," in John Donne's Personal Lives, 141.

${ }^{96}$ Grundy, Spenserian Poets, 2.

${ }^{97}$ Rachel Hile, Spenserian Satire: A Tradition of Indirection (Manchester: Manchester University Press, 2017), $147-48,86$.
} 
lines around our disciplinary communities, hold valuable information about intended audiences, and the kind of listening we hope to elicit from them.

Moreover, however frustratingly unconcrete the "sounds-like" aspects of Spenserian verse as explication, there is plainly something irresistibly easy, even instinctive, about their identification. As Grundy wrote in 1969, though "We today may not wholly approve of Hazlitt's notion of the "poetical'; nevertheless we know what he means, and can in part agree with him." 98 And as Hile has pointed out more recently, "without a literary model that seems reproducible and accessible, no one would try to write a Spenserian poem:" his "characteristic linguistic and generic mores" is easily recognisable and - more importantly for interdisciplinarity — it comprises "elements that seem accessible for imitation or adoption" to other writers" own agendas. ${ }^{99}$

One of the problems with "surface reading" as defined by Sharon Marcus and Stephen Best - the chief crux for both sponsors and opponents - is that there remains little consensus and much confusion about where to identify "the surface," and how to manage the resulting implications of what Kaye Mitchell described (a year before Marcus and Best) as an "aesthetic or interpretative hierarchy" of the different aspects which make up textual affect. ${ }^{100}$ In attempting to taxonomise the Spenserianism of Spenserians, we encounter characteristics of language-use and textual engagement which are readily (and perhaps almost instantaneously - this is not allegorymeddling) identifiable because they are easily visible and accessible, difficult to describe because they are intuitive. Do we find ourselves here, then, on a Spenserian surface? Aylett's bias against the surface and the skittery mode of travel it excites is, in theory, as firm as modern scholarship's: we must avoid and censure those who "stand in places slippery," who "of a wanton imbecillity, / Stagger and change at eu'ry idle motion," let attraction guide their will

\footnotetext{
${ }^{98}$ Grundy, Spenserian Poets, 19.

${ }^{99}$ Hile, Spenserian Satire, 69-70.

${ }^{100}$ Stephen Best and Sharon Marcus, "Surface Reading: An Introduction,” Representations 108, no. 1 (2009): 1-

21; Kaye Mitchell, Intention and Text: Towards an Intentionality of Literary Form (London: Continuum, 2008), 38.
} 
"with vaine inconstancy and leuitie," like "Wind-shaken Reeds, whose instability, / Are like the brain-sicke, idle, vaine deuotion / Of Nouellists, drunk with hot humours giddy potion."101 Rather, meditations on Constancy vs. mutability urge us to stand fast and sound on firmer ground, resolved and persevering:

\section{We Constancie a Perseuerance call}

In some good purpose: for in eu'ry thing

We vndertake, right must be first of all

Resolu'd of, next, our firme perseuering:

A vaine, vnsettled, idle wauering

Without iust ground, by Proteus, Poets faine,

Who on himselfe as many formes will bring,

As he hath idle notions in his braine,

Or base desires and Lusts which in his heart remaine. ${ }^{102}$

We may not be able to dive so deep as more learned readers, but we ought to be able to avoid being drawn idly across facades and overlays - or at the very least avoid enjoying it, in the contemptible manner of the Poet who brings upon himself as many changing forms as he has base desires.

And yet, for a thinker so theoretically evangelical about moderation, Aylett with similes and metaphors is something like a child in a china shop. Or poetry is like taking pennies from his red rag. Chief among Grundy's Spenserian attributes are: a "sliding, slipping flow," along with "need for smoothness," a passionate devotion to rhythm, and "a sense of musical delight."103 Spenserians, she remarks, "are poetry-addicts." "104 Aylett's decrees on levity are severe—but his touch is light, flighty even, and prone to the meandering of protean poets and giddy, drunken

\footnotetext{
101 Aylett, Peace with her four garders, 43, 26, 26.

102 Aylett, Peace with her four garders, 24.

${ }^{103}$ Grundy, Spenserian Poets, 68-69.

104 Ibid., 44.
} 
novellists inclined to carrying-away on poetic currents. Coursing once again Spenserian waters in Peace with her foure garders, he describes how:

Lust may be lik'ned to some Riuer maine,

Bounded by purest Channels of her owne,

Wherein so long as she her streames containe,

Her waters pleasant, pure and sweet are knowne,

But if her swelling waues so proud be growne,

They passe their Bounds, and ouerflow the Plaine,

Her flouds late pure, now foule \& muddy showne,

And boundlesse ouerflow the grasse and graine;

So rageth lawlesse Lust, let loose from Vertues raine. ${ }^{105}$

As river flows through channels to become stream, swelling with waves which really belong to the ocean, different waters brim over and into one another with haphazard overexcitement. Via an $a$ rhyme the same as the $c$, so that the already-difficult Spenserian demands five rhyming lines, with only two different end-rhymes in total, the stanza falls finally on "Vertues raine" which — brought on by dance of rhyme and aquatic overflowing - breaks free of its own watery beginnings to slip seamlessly over the heads of horses (and off them again), where the next stanza proceeds:

For we are like vnruly Horses all

Still neighing after neighbours wiues; But she

Vs, as with Bit and Bridle, doth recall,

And makes our Lusts to reasons rules agree:

Thus two as in one Body ioyned be,

And are for mutuall Bounds of sweet desire,

And bounded thus, the act is Chastitee,

${ }^{105}$ Aylett, Peace with her four garders, 16. 
Like to the vsefull Element of fier,

Which bounded all preserues; but loos'd is all's destroyer. ${ }^{106}$

And just like that, by a combination of rhyme, metaphor and pun, Aylett's courser runs from delight in different kinds of water to delight in equestrian paraphernalia - and then, through the flickering of a flame certainly produced by irresistible rhyming with "desire" (Aylett rhymes fire and desire in eight different places in Peace with her foure garders) back again, by way of the same brimming pun, to rain again:

This boundlesse Lust some liken to the Fire, And Brimstone God did downe on Sodome raine ${ }^{107}$

Flames, like waters, grow and shrink with the changeable wind - this fire roars one stanza later into "glorious Sunne," before dimming in an instant to "light on golden Candlestick."108

Caught up in the possibilities of "like" and "liken," by what is "as," and "so," or "may be lik'ned"—and without a thought, it seems, to whether "reasons rules agree"-Aylett's own poetic lusts champ at bit and bridle; they are distinctly protean, unsettled, wavering. Though straight lines - teleology, direction, consistent purpose - are the stated instructions for moving through Aylett's textual topographies, in reality the kind of reading mind they reveal is one much more suggestible to the proclivities of mutable words and phrases - to smooth sliding, and "subtile, false perswasion." 109 With an approach to movement through books more persuasively gleaned from reading the Faerie Queene than from reading the Bible, Aylett's errant souls are frequently characterised as "wandering" through wild landscapes. By the sage help, in one of very few explicit cameos, of "The aged Palmer, Spencer, Guyons trustie guide," we do not stride

\footnotetext{
${ }^{106}$ Ibid., 16.

${ }^{107}$ Ibid., 16.

${ }^{108}$ Ibid., 17.

${ }^{109}$ Aylett, Song of songs, 52.
} 
or march by roads and trails, but rather — not so trusty— “slide, / By whirle-pooles, and deepe gulfes which gape for vs so wide." 110

Working in poetry, then, inspires Aylett's thinking to more lateral cognitive slants across the surfaces of language and image. He is swept up by synonym, inclined to address everything he meets as an allegory (often fleshed out only to the slightest degree), and reluctant not to wonder down any pathway that rhyme or pun suggests. Fashioning prose into stanzas - and certainly the activity of reading scriptural prose with a view to doing so-induces a different kind of looking at words - reading for rhymes, or hearing rhymes echo across the top, blocking out thoughts into phrases and sense-units with the right number of syllables. Addison speaks, after Reuven Tsur, of "a 'couplet' frame of mind," Raphael Lyne of "Thinking in Stanzas." 111 Samuel Woodford is right that "In Verse, the Mind is quite otherwise disposed": this is an attentive methodology, a mode of thought, borrowed or learnt from poetics. Curiously, though, it evokes much less the "meeke mans [mind] like solitary place, / Where all is quiet, fit for Contemplation," than it does that "cruell mind," full of "perturbation,"

Like to a Market or tumultuous Faire,

Where all is fill'd with noise and molestation;

Durt in the streets, strong clamours in the aire ${ }^{112}$

Such places are unfit, Aylett tells us, for Graces sweet repaire. And yet his poetry maintains in its tumultuous clamour — with that which stirs, compels, moves, beguiles, overwhelms; is fervent, rapt, amazed. "Strange is the zealous fury of the rude," he writes, "When Ignorance doth guide their blinde deuotion / [...] When they be stirred with some feruent motion: / All following

\footnotetext{
110 Aylett, Brides ornaments, 22.

111 Addison, "Little Boxes," 133; Raphael Lyne, "Thinking in Stanzas," in The Work of Form, ed. Elizabeth Scott-Baumann and Ben Burton (Oxford: Oxford University Press, 2014), 88-103.

112 Aylett, Brides ornaments, 81.
} 
some brain-sick idle notion."113 The hurdy-gurdy feminine rhymes are a little brain-sickening themselves. And yet in the midst of Aylett's poetic fury, this fervent motion often proves strangely fit, and strangely affecting.

\section{Interdisciplinarity, When We "Do" It}

Interdisciplinarity at its best is often described as a conversation. This is also how Aylett, in his poem on Courtesy, describes the ideal posture of devotion:

In priuate fields, and gardens I would walke;

Now with my Muse, now with my Friends to talke:

(By Muse, I prayer meane; and Meditation,

By Friends, a holy louing Conuersation) ${ }^{114}$

Courtesy is an important aspect of ideal interdisciplinarity, too. Mannerly holiday-making in others' disciplines, or the leasing of foreign contexts or methodologies carried over into one's own (we sometimes speak, unmannerly, of "pirate raids"), can earn gracious reception in multiple camps by respectful, acknowledging attitudes towards its original sources in their original contexts. Good conversation with discourtesy is impossible: one may easier wring water from a stone, Aylett says, than mirth or gentle words from:

The base morose and cynnicall,

That to all others, manners are auerse,

Who are so crooked, crosse and criticall,

In their owne dispositions so peruerse,

No friend with them is able to conuerse,

Delighting to be conuersant with none; ${ }^{115}$

\footnotetext{
${ }^{113}$ Aylett, Brides ornaments, 14.

${ }^{114}$ Aylett, Peace with her four garders, 33.

${ }^{115}$ Ibid., 37.
} 
Open and productive both-ways conversation, then, relies on convenability. And early modern courtesy, like early modern prosody, is much preoccupied with form (what literary scholars are supposed to do), and with what Cheney has called its "generic decorum"-with questions of well and whether fitting. ${ }^{116}$

Not every kind of person in Aylett's vast cast of characters real and allegorical is well-fit to every kind of conversation. Just as a lawyer meddling in divinity must defend himself from naysayers, so too,

It doth no Judge or Magistrate become, In seruants habit publique to be seene, What Country Maid commends, may ill beseeme a Queene ${ }^{117}$

Baldwin wills in the Canticles that, "mete thinges be not vnmetely geuen, as armoure to women, nettes to studentes, nor bokes to plowmen;" here a harp is not fit for a king, and clerks ought not to hunt or hawk. ${ }^{118}$ Some, says Thrifts Equipage, are made to sweat in Husbandry, and some in "Arts or Lawes political." 119 All of these distinctions, clearly, are inflected more relevantly by questions of social status than they are by any notion of disciplinary factions. The case of Poets, though, who "may witty pleasant fictions faine, / Which in a graue Diuine would be accounted vaine," muddles it more interesting. ${ }^{120}$ Aylett's own place with regard to this last sentiment with his thoughts on poets, via Spenser and Chaucer, in mind-remains conveniently unclear. In a short paper entitled "What do we mean by Interdisciplinarity?" the Victorianist Joanne Shattock asks, "What is it that we do when we employ these different discourses, what kinds of meditations do we engage in when we 'do' it?"'121 The hobbyist, neither witty poet nor grave

\footnotetext{
116 Cheney, Spenser's Famous Flight, 103.

117 Aylett, Peace with her four garders, 47.

118 William Baldwin, The canticles or balades of Salomon, phraselyke declared in Englysh metres (London, 1549), $\mathrm{Aii}^{\mathrm{r}}$.

119 Aylett, Thrifts equipage, 11.

120 Aylett, Peace with her four garders, 47.

${ }^{121}$ Joanne Shattock, “What Do We Mean By Interdisciplinarity?,” Victorian Review 33, no. 1 (2007): 55.
} 
divine, is bound by no hard and fast affiliations to either camp. Insisting that his writing cherishes no greater aspiration than the exercising of his own mind at leisure, he is neither subject to censure nor held accountable to professional standards.

His "at leasure," as we have seen, isn't precisely candid either. For Ellinghausen's labouring authors, "to commit to writing [...] is to commit to the regular exercise of one's faculties"“daily labor keeps one not only busy, but 'honest' and spiritually 'fit". ${ }^{122}$ Aylett writes in his meditation "Of Care and Labour" that,

$$
\text { though I often am inclin'd, }
$$

The Praise of morall Vertues here to sing,

My freer Muse that will not be confin'd,

Runs straight on heau'nly contemplations string,

Else I, in other Harvests, loue not meddeling.

And yet I hope no wiser Clerkes will blame,

My boldnesse, here to taste, by meditation,

The Mysteries, whose knowledge they proclaime

To vs, as necessary for Saluation:

Thereby to square our Liues and Conuersation.

And though indeed my Writings I intend,

For others minds and manners reformation,

Yet if hereby I may mine own amend,

I haue attained more then halfe my wished end. ${ }^{123}$

Who are efforts of interdisciplinarity supposed to be for? As sometimes feels true of less successful ventures, here it is perhaps only the interdisciplinary traveller themselves, thrilled by their own discoveries between the boundaries, who learns anything by the effort of trespass; but

\footnotetext{
122 Ellinghausen, Labor and Writing, 128.

123 Aylett, Thrifts equipage, 36.
} 
as Aylett has always maintained, it was mostly on his own account anyway. "This kind of work," Lyne writes,

isn't just about expanding horizons, incorporating new heuristic methods, making fruitful contacts. It's also about exposing the tensions within one's own discipline [...] realizing the limitations of competence, encountering the foibles of another discipline and working out how to address mutual inadequacies. ${ }^{124}$

"Crossing lines," Helgerson says, "is not [...] the same as denying their existence. Indeed, my own crossings have served rather to point out the ideological function of the lines than to pretend they aren't there." ${ }^{125}$ Figuring an early modern version of interdisciplinarity is also a means for refiguring early modern approaches to distinct disciplines — and particularly for considering the appeal and the potency of the discipline of poetry. The "problem of poetic writing, circa 1579," as Harrison argues, "was not a lack of poetic theory but rather the incompatibility of different versions of poetic value." ${ }^{126}$ Consideration of Aylett's imperfectly versified meditations flashes a light on appropriatable poetic surfaces as means of defining poetic communities, coming complete with their own values and ideologies. Spenserianism-“accepting fervently the doctrine that the poet's function is educative and directed to the common good," and yet also characterised by writers for whom poetry is "a supremely enjoyable activity, releasing and invigorating," "insistent[ly] self-pleasing," "probably always more satisfying to themselves than to the reader" 127 _ offers for Aylett a mode of thought which brings the dulce et utile question importantly to bear on divine attention. His poetry, however bad, offers not a freedom from, but for seriousness.

Helgerson said that the writing of poetic amateurs had "no definable bottom, no external referent, no unambiguously ascertainable meaning;" Narveson (not specifically of poetry) that

\footnotetext{
${ }^{124}$ Lyne, "Interdisciplinarity and Anxiety," 3.

${ }^{125}$ Helgerson, Forms of Nationhood, 18.

${ }^{126}$ Harrison, "The Rude Poet," 255.

${ }^{127}$ Grundy, Spenserian Poets, 20, 8, 216.
} 
"At the heart" of lay-people's newfound self-confidence in their own written voices "is biblical knowledge." 128 This essay posits that Aylett's verse, though often delighting in its own unplaceable shifting, has many identifiable external referents and ascertainable meanings — and also the possibility that at the heart of his self-confidence in biblical knowledge is the capacity to put it into poetry. Aylett's long reworking of Du Bartas's Urania, published in 1625 with the second volume of the Bride's Ornaments (via the translation by Joshua Sylvester, probably Aylett's most major influence after Spenser), is his text most obviously and pervasively concerned with speaking the point of poetry. It's this poem I'd like to end with - an instance not of a layman "bring[ing] Scripture into their writing as that which grounds it, to which all that they say of the world or themselves must conform," 129 but rather bringing poetry into devotion and devotion into poetry, as each which makes the other fly, and stick:

Poets are like to Organs sounding shrill

With fingers touch, so long as they be full:

But as on empty ones; in vaine's our skill,

Ev'n so are Verses, without Fury, dull.

And as none on the Harpe sweet tunes can sound,

Till hee by Art hath set in Tune each string;

So none high-rapted numbers can compound,

Till's soule be tun'd by spheare-like rauishing.

Sith then to Numbers life from Heav'n is sent,

Oh rarest Spirits! how dare you abuse

Them, to dishonour him, who hath them lent

To's Glory, and your Chast delight to vse?

\footnotetext{
${ }^{128}$ Helgerson, Self-Crowned Laureates, 40; Narveson, Bible Readers, 211.

${ }^{129}$ Narveson, Bible Readers, 7.
} 


\section{$[\ldots]$}

For numbers, notes, and tunes such power haue,

They soonest on the noblest Spirits seaze;

Whereon they doe their formes and sounds engraue;

As Seales on wax imprinted are with ease. ${ }^{130}$

${ }^{130}$ Aylett, Brides ornaments, 113-114. 


\section{Bibliography}

Interdisciplinary Literary Studies. “Journal Info.” Accessed March 2, 2020. http://muse.jhu.edu/journal/555.

Addison, Catherine. 'Little Boxes: The Effects of Stanza on Poetic Narrative.' Style 37, no. 2 (2003): 124-143.

Armstrong, Nancy. "Professing Disciplinarity." Victorian Review 33, no. 1 (2007): 11-14.

Aylett, Robert. The Song of Songs, which was Salomons metaphrased in English heroiks by way of dialogue. With certayne of the brides ornaments, viz. poeticall essayes vpon a diuine subiect. Whereunto is added a funerall elegie, consecrate to the memorie of that euer honoured Lord, Iohn, late Bishop of London. By R.A. London, 1621.

—. Thrifts equipage Viz. fiue diuine and morall meditations, of 1. Frugalitie. 2. Prouidence. 3. Diligence. 4. Labour and care. 5. Death. London, 1622.

- Peace with her foure garders Viz. fiue morall meditations: of concord, chastitie, constancie. Courtesie. Grauitie. Eschew euill, and doe good, seeke peace and ensue it. London, 1622.

- Susanna: or, the arraignment of the two vniust elders. London, 1622.

- The Converts Conquest, in The brides ornaments viz. fiue meditations, morall and diuine. 1. Knowledge, 2. zeale, 3. temperance, 4. bountie, 5. ioy. London, 1625.

- Divine, and moral speculations in metrical numbers, upon various subjects. By Doctor R. Aylet, one of the masters of the High Court of Chancery. Urania, or the heavenly muse. Urania, or the heavenly muse. London, 1654.

- Devotions viz. 1. A good womans 2. The humble mans prayer. Praeceptis ducimur, exemplis trahimur. Precepts in Gods most holy law do us direct; examples draw. By R.A. D.L. London, 1655. 
Baldwin, William. The canticles or balades of Salomon, phraselyke declared in Englysh metres. London, 1549.

Baroway, Israel. "The Imagery of Spenser and the "Song of Songs." The Journal of English and Germanic Philology 33, no. 1 (1934): 23-45.

Best, Stephen and Sharon Marcus. “Surface Reading: An Introduction.' Representations 108, no. 1 (2009): 1-21.

Chaucer, Geoffrey. House of Fame. In The Riverside Chaucer, edited by Larry D. Benson and Fred Norris, third edition, with foreword by Christopher Cannon. Oxford: Oxford University Press, 2008.

Cheney, Patrick. Spenser's Famous Flight: A Renaissance Idea of a Literary Career. London: University of Toronto Press, 1993.

Clarke, Elizabeth. Politics, Religion and the Song of Songs in Seventeenth-Century England. Basingstoke: Palgrave Macmillan, 2011.

Colclough, David. “Introduction: Donne's Professional Lives.” In John Donne's Professional Lives, edited by David Colclough, 1-19. Cambridge: D. S. Brewer, 2003.

Deutermann, Allison K. and András Kiséry. Formal Matters: Reading the Material of English Renaissance Literature. Manchester: Manchester University Press, 2013.

Dolven, Jeff. “The Method of Spenser's Stanza.” Spenser Studies 19, no. 1 (2004): 17-25.

Ellinghausen, Laurie. Labor and Writing in Early Modern England, 1567-1667. Aldershot: Ashgate, 2008.

Esolen, Anthony M.. “The Disingenuous Poet Laureate: Spenser's Adoption of Chaucer," Studies in Philology 87, no. 3 (1990): 285-311. 
Flinker, Noam. The Song of Songs in English Renaissance Literature: Kisses of their Mouths. Cambridge: D. S. Brewer, 2000.

—_. "Aylett, Robert." In The Spenser Encyclopedia, edited by A. C. Hamilton, 77-78. London: Routledge, 1990.

Frodeman, Robert. The Oxford Handbook of Interdisciplinarity, edited by Robert Frodeman, Julie Thompson Klein and Carl Mitcham. Oxford: Oxford University Press, 2010.

Grundy, Joan. The Spenserian Poets: A Study in Elizabethan and Jacobean Poetry. London: Edward Arnold, 1969.

Harrison, Matthew. "The Rude Poet Presents Himself: Breton, Spenser, and Bad Poetry," Spenser Studies: A Renaissance Poetry Annual 29, no.1 (2014): 239-262.

Hayward, John. The first part of the life and raigne of King Henrie the IIII. Extending to the end of the first yeare of his raigne. Written by I.H. . London, 1599.

- The first part of the sanctuarie of a troubled soule. London, 1610.

—. Davids Teares. London, 1622.

Hazlitt, William. “On Chaucer and Spenser.” In Lectures on the English Poets: Delivered at the Surrey Institution, 39-85. London: Taylor and Hessy, 1818.

Helgerson, Richard. Self-Crowned Laureates: Spenser, Jonson, Milton and the Literary System. Berkeley: University of California Press, 1983.

- Forms of Nationhood: The Elizabethan Writing of England. University of Chicago Press, 1992.

Hile, Rachel. Spenserian Satire: A Tradition of Indirection. Manchester: Manchester University Press, 2017. 
Hunt, Arnold. The Art of Hearing: English Preachers and their Audiences, 1590-1640. Cambridge: Cambridge University Press, 2010.

Hunter Jr., William B.. The English Spenserians: The Poetry of Giles Fletcher, George Wither, Michael Drayton, Phineas Fletcher, and Henry More. Salt Lake City: University of Utah Press, 1977.

Krohn, Wolfgang. "Interdisciplinary Cases and Disciplinary Knowledge." In The Oxford Handbook of Interdisciplinarity, The Oxford Handbook of Interdisciplinarity, edited by Robert Frodeman, Julie Thompson Klein and Carl Mitcham, 31-39. Oxford: Oxford University Press, 2010.

Lander, Jesse M.. Inventing Polemic: Religion, Print, and Literary Culture in Early Modern England. Cambridge: Cambridge University Press, 2006.

Lyne, Raphael, “Interdisciplinarity and Anxiety.” Palgrave Communications 1 (2015): 2-3.

—. "Thinking in Stanzas." In The Work of Form, edited by Elizabeth Scott-Baumann and Ben Burton, 88-103. Oxford: Oxford University Press, 2014.

Manning, John J., "Hayward, Sir John,” Oxford Dictionary of National (January 3, 2008). Accessed March 2, 2020, https://doi.org/10.1093/ref:odnb/12794.

Maule, Jeremy. "John Donne and the Words of the Law." In John Donne's Professional Lives, edited by David Colclough, 19-37. Cambridge: D. S. Brewer, 2003.

Mitchell, Kaye. Intention and Text: Towards and Intentionality of Literary Form. London: Continuum, 2008.

Moran, Joe. Interdisciplinarity. London: Routledge, 2010.

Narveson, Kate. “Donne the Layman Essaying Divinity.” John Donne Journal 28 (2009): 130. 
—. Bible Readers and Lay Writers in Early Modern England. Farnham: Ashgate, 2012.

O'Callaghan, Michelle. The "Shepheard's Nation": Jacobean Spenserians and Early Stuart Political Culture, 1612-25. Oxford: Clarendon, 2000.

Padelford, Frederick. "Robert Aylett." The Huntington Library Bulletin 10 (1936): 1-48.

—_. "Robert Aylett: A Supplement." Huntington Library Quarterly 2 (1939): 471-478.

Perloff, Marjorie. "Presidential Address 2006: It Must Change.” PMLA 122, no. 3 (2007): $652-662$.

Peterson, Linda. "The Concept of Literature and the Practice of Interdisciplinarity" Victorian Review 33, no. 1 (2007): 47-51.

Shami, Jeanne. "Labels, Controversy, and the Language of Inclusion in Donne's Sermons." In John Donne's Professional Lives, edited by David Colclough, 135-159. Cambridge: D. S. Brewer, 2003.

Shattock, Joanne. "What Do We Mean By Interdisciplinarity?" Victorian Review 33, no. 1 (2007): 55-58.

Spenser, Edmund. The Shepheardes Calender. In The Yale Edition of the Shorter Poems of Edmund Spenser, edited by William A. Oram, Einar Bjorvand, Ronald Bond, Thomas H, Cain, Alexander Dunlop and Richard Schell, 1-214. London: Yale University Press, 1989.

—. The Faerie Queene, edited by A. C. Hamilton. Harlow: Longman, 2001.

Steggle, Matthew. “Aylett, Robert.” Oxford Dictionary of National Biography (September 23, 2004). Accessed March 2, 2020. https://doi.org/10.1093/ref:odnb/932.

Steinberg, Glenn A.. 'Spenser's 'Shepheardes Calender' and the Elizabethan Reception of Chaucer." English Literary Renaissance 35, no. 1 (2005): 31-52. 
Tsur, Reuven. "Rhyme and Cognitive Poetics.” Poetics Today 17 (1996): 55-87.

Wood, Anthony à. Athenae Oxonienses : an exact history of all the writers and bishops who have had their education in the University of Oxford: to which are added the Fasti, or Annals of the said University. London, 1813.

Woodford, Samuel. A Paraphrase upon the Canticles, and some select hymns of the New and Old Testament with other occasional compositions in English verse. London, 1679. 